NASA/TM-2000-210473

\title{
NDE Methodologies for Composite Flywheels Certification
}

George Y. Baaklini and Kevin E. Konno

Glenn Research Center, Cleveland, Ohio

Richard E. Martin

Cleveland State University, Cleveland, Ohio

Richard Thompson

University of Texas at Austin, Austin, Texas 
Since its founding, NASA has been dedicated to the advancement of aeronautics and space science. The NASA Scientific and Technical Information (STI) Program Office plays a key part in helping NASA maintain this important role.

The NASA STI Program Office is operated by Langley Research Center, the Lead Center for NASA's scientific and technical information. The NASA STI Program Office provides access to the NASA STI Database, the largest collection of aeronautical and space science STI in the world. The Program Office is also NASA's institutional mechanism for disseminating the results of its research and development activities. These results are published by NASA in the NASA STI Report Series, which includes the following report types:

- TECHNICAL PUBLICATION. Reports of completed research or a major significant phase of research that present the results of NASA programs and include extensive data or theoretical analysis. Includes compilations of significant scientific and technical data and information deemed to be of continuing reference value. NASA's counterpart of peerreviewed formal professional papers but has less stringent limitations on manuscript length and extent of graphic presentations.

- TECHNICAL MEMORANDUM. Scientific and technical findings that are preliminary or of specialized interest, e.g., quick release reports, working papers, and bibliographies that contain minimal annotation. Does not contain extensive analysis.

- CONTRACTOR REPORT. Scientific and technical findings by NASA-sponsored contractors and grantees.
- CONFERENCE PUBLICATION. Collected papers from scientific and technical conferences, symposia, seminars, or other meetings sponsored or cosponsored by NASA.

- SPECIAL PUBLICATION. Scientific, technical, or historical information from NASA programs, projects, and missions, often concerned with subjects having substantial public interest.

- TECHNICAL TRANSLATION. Englishlanguage translations of foreign scientific and technical material pertinent to NASA's mission.

Specialized services that complement the STI Program Office's diverse offerings include creating custom thesauri, building customized data bases, organizing and publishing research results ... even providing videos.

For more information about the NASA STI Program Office, see the following:

- Access the NASA STI Program Home Page at http://www.sti.nasa.gov

- E-mail your question via the Internet to help@sti.nasa.gov

- Fax your question to the NASA Access Help Desk at (301) 621-0134

- Telephone the NASA Access Help Desk at (301) 621-0390

- Write to:

NASA Access Help Desk

NASA Center for AeroSpace Information 7121 Standard Drive

Hanover, MD 21076 
NASA/TM-2000-210473

\section{NDE Methodologies for Composite Flywheels Certification}

George Y. Baaklini and Kevin E. Konno

Glenn Research Center, Cleveland, Ohio

Richard E. Martin

Cleveland State University, Cleveland, Ohio

Richard Thompson

University of Texas at Austin, Austin, Texas

Prepared for the

2000 Power Systems Conference

sponsored by the Society of Automotive Engineers

San Diego, California, October 31-November 2, 2000

National Aeronautics and

Space Administration

Glenn Research Center 
Available from

NASA Center for Aerospace Information 7121 Standard Drive

Hanover, MD 21076

Price Code: A03
National Technical Information Service 5285 Port Royal Road Springfield, VA 22100 Price Code: A03

Available electronically at http://gltrs.grc.nasa.gov/GLTRS 


\title{
NDE Methodologies for Composite Flywheels Certification
}

\author{
George Y. Baaklini and Kevin E. Konno \\ National Aeronautics and Space Administration \\ Glenn Research Center \\ Cleveland, Ohio 44135 \\ Richard E. Martin \\ Cleveland State University \\ Cleveland, Ohio 44115 \\ Richard Thompson \\ University of Texas, CEM \\ Austin, Texas 78712
}

\begin{abstract}
Manufacturing readiness of composite rotors and certification of flywheels depend in part on the maturity of nondestructive evaluation (NDE) technology for process optimization and quality assurance, respectively. Capabilities and limitations of $x$-ray-computed tomography and radiography, as well as advanced ultrasonics were established on NDE ring and rotor standards with EDM notches and drilled holes. Also, intentionally seeded delamination, tow break, and insert of bagging material were introduced in hydroburst-rings to study the NDE detection capabilities of such anomalies and their effect on the damage tolerance and safe life margins of subscale rings and rotors. Examples of possible occurring flaws or anomalies in composite rings as detected by NDE and validated by destructive metallography are shown. The general NDE approach to ensure quality of composite rotors and to help in the certification of flywheels is briefly outlined.
\end{abstract}

\section{INTRODUCTION}

The flywheel technology for energy storage systems is gaining broader support, more than it did for the last 25 years [1-4], because of current support from NASA and U.S. Air Force space programs. The drive is not only to improve energy storage systems where the state of charge can be known but also to concurrently perform attitude control depending on the specific application for a given spacecraft [5]. Some of the major challenges in the flywheel technology for the international space station (ISS) include high-speed rotors and carbon reinforced composite materials that can meet the safelife design requirements, reliability and durability to endof-life, flight certification, and safety constraints while delivering the high energy density needed [6]. In this paper, the research is limited to the NDE of composite flywheel rotors and rings that are targeted under the flywheel energy storage system (FESS) program [7]. These composite rotors are to be flown on the ISS replacing a battery charge/discharge unit.

\section{MATERIALS AND NDE METHODS AND STANDARDS}

The composite materials under investigation, the NDE methods employed, and the NDE standards are all described in the following sections:

MATERIALS - Composite flywheel rings and rotors were fabricated using proprietary materials and processes. The composite material system consists of polymer matrix composites (PMCs), using toughened resin systems, with added features to enhance fracture toughness for the laminate and prevent/mitigate the formation of cracks. This fabrication process is autoclave based, to assist with consolidation and to reduce void content.

The flywheel, see Fig.1, consists of a solid cylindrical composite energy storage unit made of concentric rings press fit (preloaded) together, operating with a rotor tip speed approximately $835 \mathrm{~m} / \mathrm{s}$.

NDE METHODS - Several ultrasonic methods were used for the material characterization of the composite rotors. Through-transmission (TT) and pulse-echo (PE) methodologies were used for flaw detection and acoustoultrasonics (AU) and ultrasonic spectroscopy (US) were used for degradation and damage assessment before and after fatigue or burst tests. In this paper we limit our discussion to the TT and PE ultrasonic scanning methods suitable for flaw detection. Several x-ray methods were used like conventional and microfocus radiography and $420 \mathrm{KeV}$ and $3 \mathrm{MeV}$ computed 
tomography (CT). Conventional and microfocus radiography were used for flaw detection and composite architecture verification. Low energy CT, $420 \mathrm{KeV}$, was used for thin rings and thin-rim rotors whereas high energy $\mathrm{CT}, 2-3 \mathrm{MeV}$, was used for thick composite rings and thick-rim rotors with hubs. Conventional and microfocus radiography were used in the 40 to $80 \mathrm{KeV}$ and $5 \mathrm{~mA}$ to $0.4 \mathrm{~mA}$, respectively.

Pulse Echo and Through Transmission Ultrasonics Figure 2 shows the immersion ultrasonic scanning system during a PE inspection of one composite ring. PE is an ultrasonic method in which only one transducer is used to send the sound into the material and then to receive the sound after it bounces off the back surface of the object under inspection. TT is an ultrasonic method in which two transducers are used, one to send the sound from one side into the object under investigation, and a second transducer to receive the sound after it traversed the object. This method requires access to both front (OD) and back (ID) surfaces of objects like composite rings and rotors without a metallic hub. PE method is better suited for the evaluation of an object with one side access similar to the case of a composite rotor with a hub. Both TT and PE methods provide information on the internal state of the material by studying the attenuation mechanisms that take place during the traverse of sound through the material.

X-ray Computed Tomography and Radiography - Figure 3 shows a schematic of $x$-ray computed tomography setup where the object under inspection is rotated at small increment angles, 0.2 degree, collecting many projections from the $x$-ray fan beam after it attenuates through the object and is received at the detector. These projections are then built in the Fourier domain allowing fast inverse Fourier algorithms to be utilized for reconstructing the $\mathrm{CT}$ cross-section, called the $\mathrm{CT}$ slice, information at a specific location or height. The CT slice reveals internal mass attenuation coefficient differences due to the presence of different material compositions or features. These differences can be attributed to and correlated with density differences between material constituents. X-ray radiography on the other hand, a simpler imaging method than $\mathrm{CT}$, uses the same principle of $\mathrm{x}$-ray attenuation. In conventional and microfocus radiography the $x$-ray beam is in general conical in shape as opposed to the fan shape in CT, and the resulting image/radiograph is a $2 \mathrm{D}$ shadowgram that superimpose all information in the $x$-ray path. In microfocus radiography, the spatial resolution and contrast sensitivity are improved by comparison to conventional radiography because the focal spot size of the microfocus $x$-ray tube is on the order of $5-50 \mu \mathrm{m}$ whereas that of a conventional tube is $400 \mu \mathrm{m}$ and above. Also, the projection mode in microfocus radiography reduces the scattered radiation which normally deteriorate the signal to noise ratio in the directcontact conventional-radiography mode.

NDE STANDARDS - The NDE standards were made to establish the capabilities and limitations of the NDE methods employed, and to use them as NDE reference standards to ensure that the NDE methods employed were performing to specifications every time they were used.

Composite Ring Standard - Figure 4 is a schematic of a typical ring standard with EDM notches ranging from $125 \times 125 \mu \mathrm{m}$ to $750 \times 1500 \mu \mathrm{m}(5 \times 5$ mils to $30 \times 60$ mils $)$ and drilled holes ranging from $300 \mu \mathrm{m}$ to $1600 \mu \mathrm{m}$ (12 mil to $1 / 16 ")$ in diameter. These notches and drilled holes were $12.5 \mathrm{~mm}(1 / 2 ")$ deep in a $12.5 \mathrm{~mm}(1 / 2 ")$ wide by $12.5 \mathrm{~mm}(1 / 2 ")$ high composite ring.

Composite Rotor Standard - Figure 5 is a CT slice of a multi-layered rotor standard. The hub is made of Ti-6Al$4 \mathrm{~V}$ and the rim is a multi-layered PMC. The same set of EDM notches and drilled holes $(125 \times 125 \mu \mathrm{m}, 300 \mu \mathrm{m}$, $390 \mu \mathrm{m}, 500 \times 500 \mu \mathrm{m}, 780 \mu \mathrm{m}$, and $750 \times 1500 \mu \mathrm{m})$ was machined into each of the eight composite layers. The set was duplicated in a spiral fashion starting at the innermost ring at the ID to the outermost one at the OD.

\section{RESULTS AND DISCUSSION}

Ring Standard - Table I shows all the NDE findings taken on two standard rings by using ultrasonic TT and PE methods, conventional as well as microfocus radiography and $420 \mathrm{KeV}$ and $3 \mathrm{MeV}$ x-ray CT methods. The microfocus radiography images of one of the standard ring are shown in figure 6. The ultrasonic images are shown in figures 7 and 8 . From table I findings and figure 6 images microfocus radiography was demonstrated to be a viable NDE technique to detect EDM notches and drilled holes down to a $125 \times 125 \mu \mathrm{m}$ notch and $300 \mu \mathrm{m}$ drilled hole. Conventional radiography was capable of detecting EDM notches down to 250x750 $\mu \mathrm{m}$ and drilled holes down to $780 \mu \mathrm{m}$ in diameter. However, conventional radiography is capable of detecting metallic inclusion down to $125 \times 125 \mu \mathrm{m}$. Computed tomography findings demonstrate that EDM notches down to $125 \times 125 \mu \mathrm{m}$ and drilled holes down to $300 \mu \mathrm{m}$ in diameter can be easily detected by $420 \mathrm{KeV}$ as well as by a $3 \mathrm{MeV}$ systems. The PE ultrasonic method was found to be capable of detecting EDM notches down to $125 \times 125 \mu \mathrm{m}$ and drilled holes down to $300 \mu \mathrm{m}$ in diameter. TT method was capable of detecting EDM notches down to $125 \times 1000 \mu \mathrm{m}$ and drilled holes down to $780 \mu \mathrm{m}$ in diameter.

Rotor Standard - All EDM notches and drilled holes were detected in all composite layers by using $3 \mathrm{MeV}$ CT. The 
selected CT slice shown in figure 5 substantiates the finding. This is a major result for high energy $\mathrm{CT}$ to detect low-density flaw down to $125 \times 125 \mu \mathrm{m}$ in a thickrim rotor. This further demonstrates that $\mathrm{x}$-ray $\mathrm{CT}$ can play a major role in rotor flight certification. Ultrasonic scanning results, not shown herein because of space limitation, demonstrated 1) penetration capabilities of 4.5 $\mathrm{cm}$ and detection capabilities down to $750 \times 1500 \mu \mathrm{m}$ (30x60 mils) in the outermost ring only for the case of 1 $\mathrm{MHz}$, 2) penetration capabilities of $2 \mathrm{~cm}$ and detection capabilities of the whole set in the outermost ring and down to $500 \times 500 \mu \mathrm{m}(20 \times 20$ mils) in the second ring from the $\mathrm{OD}$ at $2.25 \mathrm{MHz}$, and 3) penetration capabilities of $2 \mathrm{~cm}$ and detection capabilities of the whole set in the first two ring from the OD.

Seeded Delamination and Bagging Materials - A delamination was created in one hydroburst ring that spans 180 degrees of the circumference at midpoint in the radial direction. An optical photograph of a selected section of the delamination is shown in figure 9 where the schematic of propagating ultrasound bouncing off the I.D. surface of the ring is also depicted. The time domain of the ultrasound signal highlights the presence of the delamination, second peak, between the front surface reflection, peak 1 , and back surface reflection, peak 3 . Gating the second peak in the time domain, the delamination, resulted in imaging the presence of the delamination (echo coming from the wall/interface created by the delamination) between $180^{\circ}$ and $0^{\circ}$ (clock wise) as shown in the top of figure 9.

Figure 10 shows the ultrasonic PE scan of the hydroburst ring with seeded insert of bagging material located at 120 degree in the middle of the $4 \mathrm{~mm}$ thick by $12.7 \mathrm{~mm}$ wide ring. The insert was easily detected by PE ultrasonics and is depicted as a black line at the $120^{\circ}$. angle location at the top of figure 10. The tow-break was simulated by an EDM notch on the ID surface of a hydroburst ring. The notches were easily detected because they were comparable to the larger EDM notches imaged in the ring standard as shown previously in figures 6-8 and Table I.

Examples of Possible Occurring Flaws - Figure 11 shows a large delamination in one of the rings as detected by PE ultrasonic method. This delamination spans a 54degree angle near the bottom edge, and is $15 \mathrm{~cm}$ in height. The optical photograph of a section of the ring as exposed to the surface shows clear evidence of that delamination in figure 12. Figure 13 shows a sizeable void, about $1 \times 2 \mathrm{~mm}$ (40x80 mils), at the glass-composite interface as detected by $x$-ray $\mathrm{CT}$. The glass layer was machined off and the low-density feature as detected by CT was demonstrated to be a void. A selected area from a CT slice of a composite ring is shown in figure 14(a). The dark region, lower-density feature near the I.D., depicts the presence of a resin rich area. After the ring

NASA/TM-2000-210473 was sectioned destructively and the specific location was exposed to the surface and polished, the optical photograph (Fig. 14b) confirms the CT findings of the resin rich area.

General NDE Approach Toward Flywheel Certification The current NDE plan, to ensure quality of composite rotors and to help in the certification of flywheels, based on the findings in this work is to 1) perform flaw/damage detection on $100 \%$ of the rings with P-E ultrasonics and real-time microfocus radiography and selected slices with computed tomography, 2) perform flaw/damage detection on $100 \%$ of the rotor with thick computed tomography slices and $100 \%$ of the outer shells with $5 \mathrm{MHz} \mathrm{P}-\mathrm{E}$ ultrasonics down to $2 \mathrm{~cm}$ deep from the OD of the rotor, and 3) perform general c-scan evaluation with $0.5 \mathrm{MHz}$ P-E ultrasonics down to $4.5 \mathrm{~cm}$ deep from the OD of the rotor. Further, based on work by Baaklini et.al., [8], and by Harmon and Baaklini [9] not reported herein, NDE for material characterization and degradation assessment of mechanical properties and interfaces is to be performed on $100 \%$ of the rotors via acoustoultrasonics and ultrasonic resonance spectroscopy.

\section{CONCLUSION}

Capabilities and limitations of x-ray-computed tomography and radiography, as well as advanced ultrasonics were established on nondestructive evaluation (NDE) ring and rotor standards with EDM notches and drilled holes. EDM notches down to 125 by $125 \mu \mathrm{m}$ and drilled holes down to $300 \mu \mathrm{m}$ in diameter were detected in a thick multi-layered rotor by using $x$ ray computed tomography. At the ring level, x-ray microfocus radiography, $x$-ray computed tomography, and pulse echo ultrasonic scans were able to detect EDM notches down to 125 by $125 \mu \mathrm{m}$ and drilled holes down to $300 \mu \mathrm{m}$ in diameter. Intentionally seeded delamination, tow break, and insert of bagging material were easily detected in hydroburst rings by using the ultrasonic pulse echo method. Possible occurring anomalies like delamination in polymer matrix composite layers, void in glass layers, and resin rich regions in the composite layers, were all detected by NDE and verified by metallography. The general NDE approach to ensure quality of composite rotors and to help in the certification of flywheels was briefly outlined.

\section{REFERENCES}

1. DeTersa, S.J., "Materials for Advanced Flywheel Energy-Storage Devices," MRS Bulletin November, 1999, pp 51-55.

2. Olszewski, M. et.al ," On the Fly or Under Pressure," Mechanical Engineering June 1988, pp 50-58.

3. Ashley, S.," Flywheel Put a New Spin on Electric Vehicles," Mechanical Engineering, October 1993, pp 44-51. 
4. Moritz, B., " Composites Maximize Energy Storage in Industrial Flywheels," Composites, March/April 1998, pp 21-24.

5. Brown, P.J., " Flywheels in Space," Launchspace, September 2000, pp 22-25.

6. Konno, K.E., et.al.," Certification of High Speed Flywheel Rotors for the International Space Station, " SAE 2000 Power Systems Conference, San Diego, October 31-November 2nd 2000.

7. http://space-power.grc.nasa.gov/ppo/flywheel/

8. Baaklini, G.Y. et.al., " NDE for Material Characterization in Aeronautic and Space Applications," presented at the MicroMAt 2000 in Berlin, Germany, April 2000. NASA TM in publication.

9. Laura M. Harmon, George Baaklini "Ultrasonic Spectroscopy Of Flywheel Composite Material Systems", To be presented at the NDE for Health Monitoring and Diagnostics Symposium, SPIE, March 4-8, 2001, Newport Beach, CA. NASA TM\# in publication. 


\begin{tabular}{|c|c|c|c|c|c|c|c|c|c|}
\hline & \multicolumn{5}{|c|}{ Standard ring \#1 } & \multicolumn{4}{|c|}{ Standard ring \#2 } \\
\hline $\begin{array}{c}\text { Defect Size } \\
\mu \mathrm{m}\end{array}$ & $\begin{array}{l}\text { UT } \\
\text { TT }\end{array}$ & $\begin{array}{l}\text { RT } \\
\text { C }\end{array}$ & $\begin{array}{l}\text { RT } \\
\text { M }\end{array}$ & $\begin{array}{l}\text { CT } \\
420 \\
\mathrm{KeV}\end{array}$ & $\begin{array}{l}\text { CT } \\
3 \\
\text { MeV }\end{array}$ & $\begin{array}{l}\text { UT } \\
\text { PE }\end{array}$ & $\begin{array}{l}\text { RT } \\
\text { M }\end{array}$ & $\begin{array}{l}\text { CT } \\
420 \\
\mathrm{KeV}\end{array}$ & $\begin{array}{l}\text { CT } \\
3 \\
\text { MeV }\end{array}$ \\
\hline $125 \times 125$ & - & hd & $\mathbf{x}$ & - & $\mathbf{x}$ & $\mathbf{x}$ & $\mathbf{x}$ & $\mathbf{x}$ & $\mathbf{x}$ \\
\hline $125 \times 500$ & - & - & $\mathbf{x}$ & $\mathbf{x}$ & - & $\mathbf{x}$ & $\mathbf{x}$ & $\mathbf{x}$ & $\mathbf{x}$ \\
\hline $125 \times 750$ & - & - & $\mathbf{x}$ & $\mathbf{x}$ & $\mathbf{x}$ & $\mathbf{x}$ & $\mathrm{x}$ & $\mathrm{x}$ & $\mathbf{x}$ \\
\hline $125 \times 1000$ & $\mathbf{x}$ & - & $\mathbf{x}$ & $\mathbf{x}$ & $\mathbf{x}$ & $\mathbf{x}$ & $\mathbf{x}$ & $\mathbf{x}$ & $\mathbf{x}$ \\
\hline $250 \times 250$ & $\mathbf{x}$ & - & $x$ & $\mathbf{x}$ & $\mathbf{x}$ & $\mathbf{x}$ & $x$ & $\mathbf{x}$ & $\mathbf{x}$ \\
\hline $250 \times 500$ & $\mathbf{x}$ & hd & $\mathbf{x}$ & $\mathbf{x}$ & $\mathbf{x}$ & $\mathbf{x}$ & $\mathbf{x}$ & $\mathbf{x}$ & $\mathbf{x}$ \\
\hline $250 \times 750$ & $\mathbf{x}$ & $\mathrm{x}$ & $\mathrm{x}$ & $x$ & $\mathbf{x}$ & $x$ & $\mathbf{x}$ & $\mathbf{x}$ & $\mathbf{x}$ \\
\hline $250 \times 1000$ & $\mathbf{x}$ & $\mathrm{x}$ & $\mathbf{x}$ & $\mathbf{x}$ & $\mathbf{x}$ & $\mathbf{x}$ & $\mathbf{x}$ & $\mathbf{x}$ & $\mathbf{x}$ \\
\hline $500 \times 500$ & $\mathbf{x}$ & $\mathbf{x}$ & $\mathbf{x}$ & $\mathrm{x}$ & $x$ & $x$ & $x$ & $x$ & $\mathrm{x}$ \\
\hline $500 \times 1500$ & $\mathrm{x}$ & $\mathrm{x}$ & $\mathrm{x}$ & $\mathbf{x}$ & $\mathbf{x}$ & $\mathbf{x}$ & $\mathbf{x}$ & $\mathbf{x}$ & $\mathbf{x}$ \\
\hline $750 \times 750$ & $\mathbf{x}$ & $\mathbf{x}$ & $\mathbf{x}$ & $\mathbf{x}$ & $\mathbf{x}$ & $\mathbf{x}$ & $\mathbf{x}$ & $\mathbf{x}$ & $\mathbf{x}$ \\
\hline $750 \times 1500$ & $\mathbf{x}$ & $\mathrm{x}$ & $\mathrm{x}$ & $\mathbf{x}$ & $\mathrm{x}$ & $\mathbf{x}$ & $\mathbf{x}$ & $\mathbf{x}$ & $\mathbf{x}$ \\
\hline 390 & - & - & $\mathbf{x}$ & $\mathbf{x}$ & $\mathbf{x}$ & $\mathbf{x}$ & $\mathbf{x}$ & $\mathbf{x}$ & $\mathbf{x}$ \\
\hline 780 & $\mathbf{x}$ & $x$ & $\mathbf{x}$ & $\mathbf{x}$ & $\mathrm{x}$ & $\mathbf{x}$ & $\mathbf{x}$ & $\mathbf{x}$ & $\mathbf{x}$ \\
\hline $\begin{array}{l}\text { Cluster of } \\
390\end{array}$ & $\mathbf{x}$ & $\mathbf{x}$ & $\mathbf{x}$ & $\mathbf{x}$ & $\mathbf{x}$ & $\mathbf{x}$ & $\mathbf{x}$ & $\mathbf{x}$ & $\mathbf{x}$ \\
\hline $\begin{array}{l}\text { Cluster of } \\
780\end{array}$ & $\mathbf{x}$ & $\mathbf{x}$ & $\mathbf{x}$ & $\mathbf{x}$ & $\mathbf{x}$ & $\mathbf{x}$ & $\mathrm{x}$ & $\mathbf{x}$ & $\mathbf{x}$ \\
\hline 300 & - & hd & $\mathbf{x}$ & $\mathbf{x}$ & $x$ & $\mathbf{x}$ & $\mathbf{x}$ & $\mathbf{x}$ & $\mathbf{x}$ \\
\hline 1170 & $x$ & $\mathbf{x}$ & $\mathbf{x}$ & $\mathrm{x}$ & $\mathbf{x}$ & $\mathbf{x}$ & $\mathbf{x}$ & $\mathbf{x}$ & $\mathbf{x}$ \\
\hline 1560 & $\mathbf{x}$ & $\mathbf{x}$ & $\mathbf{x}$ & $\mathbf{x}$ & $\mathrm{x}$ & $\mathbf{X}$ & $\mathbf{x}$ & $\mathbf{x}$ & $\mathbf{x}$ \\
\hline
\end{tabular}

Table I. - NDE detection capabilities of EDM notches and drilled holes in standard ring \#1 and standard ring \#2. (hd is short for high density broken metallic EDM wire; UT is ultrasonic testing; TT is through transmission; $\mathrm{PE}$ is pulse echo; $\mathrm{RT}$ is radiographic testing; $\mathrm{C}$ is conventional; $\mathrm{M}$ is microfocus; $\mathrm{CT}$ is computed tomography 


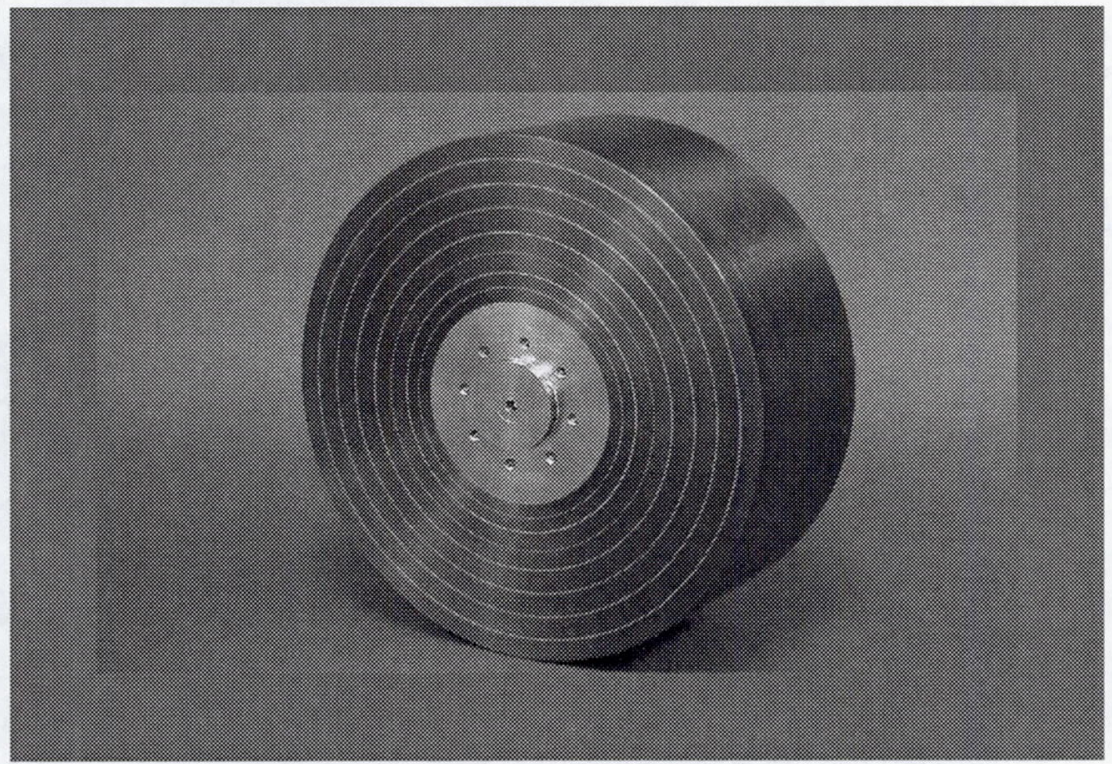

Fig. 1- Preloaded composite rotor for the flywheel energy storage system targeting the replacement of chemical batteries on the international space station

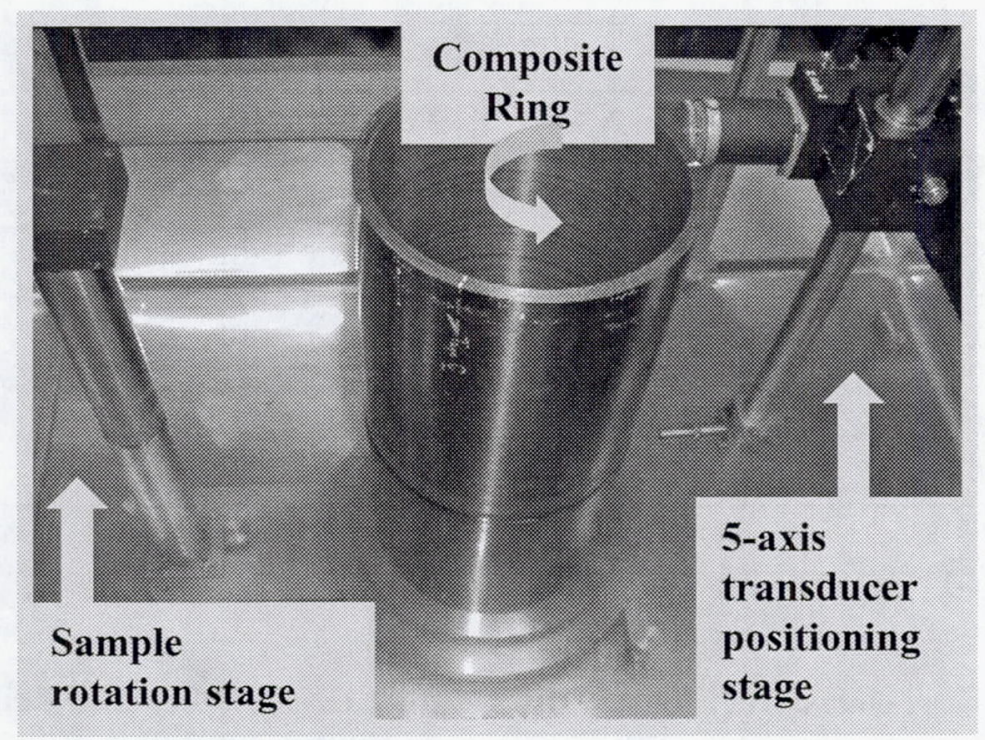

Fig. 2.- Immersion ultrasonic scanning system as applied to composite ring evaluation 


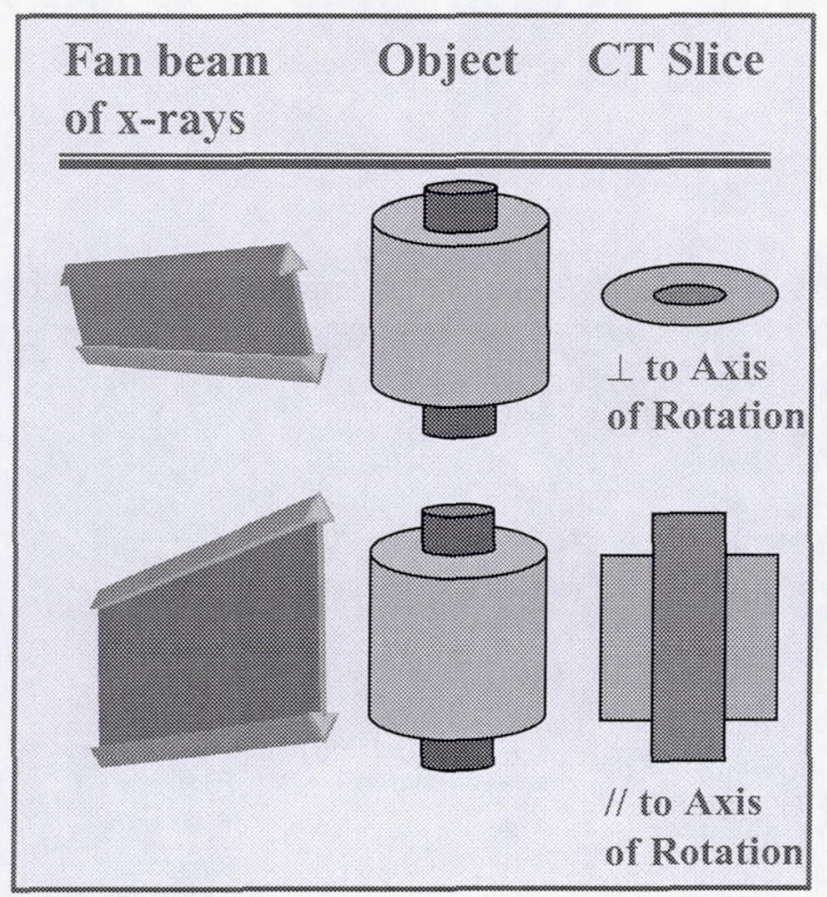

Fig. 3.- Schematic of $x$-ray computed tomography as applied to composite rotor evaluation

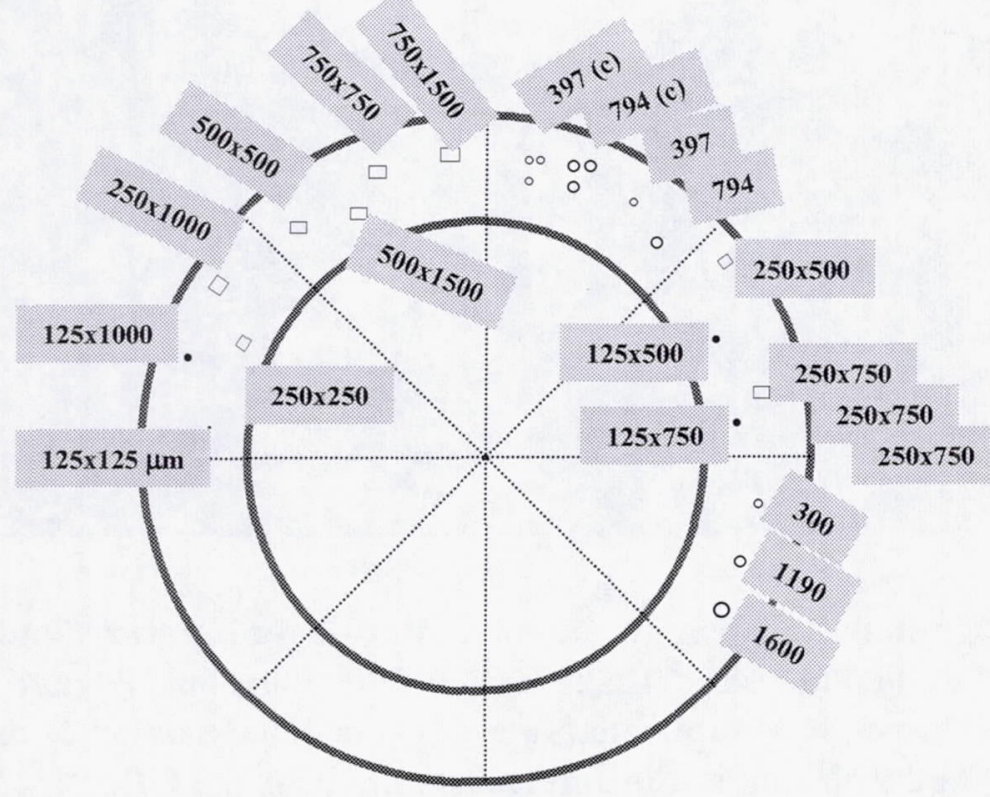

Fig. 4- Schematic of a nondestructive evaluation ring standard with EDM notches and drilled holes. Ring is $\mathbf{1 2 . 5} \mathbf{m m}$ high and $\mathbf{1 2 . 5} \mathrm{mm}$ thick, and notches and holes are $\mathbf{6 . 2 5}$ mm deep. Measurements shown on figure are in micrometers and the schematic is not to scale. $C$ in 397 ( c ) stands for cluster of $397 \mu \mathrm{m}$ drilled holes. 


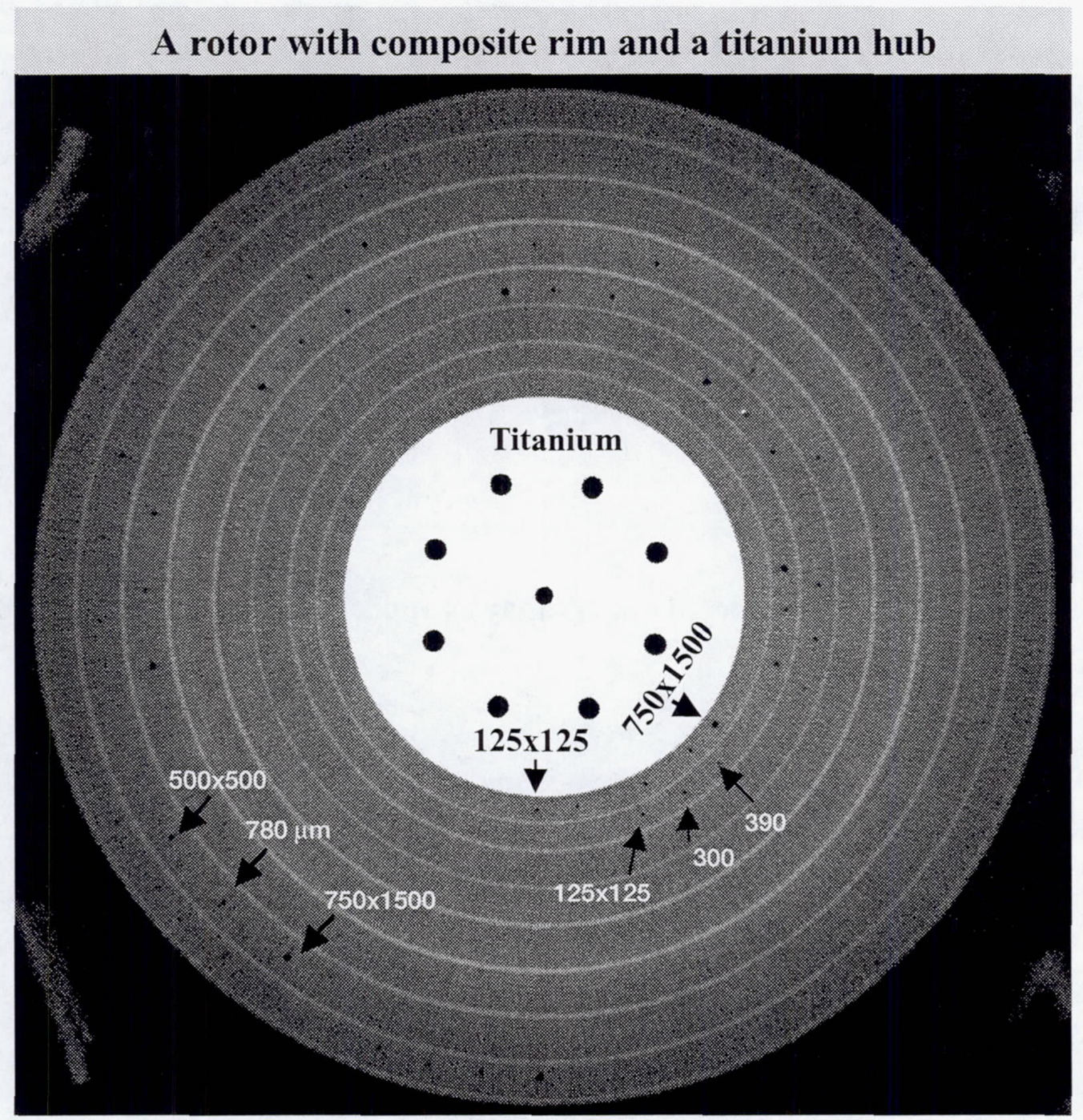

Fig. 5 - Computed tomography slice of a multi-layered rotor standard with EDM notches and drilled holes set $(125 \times 125,300,390,500 \times 500,780$, and $750 \times 1500 \mu \mathrm{m})$ in each layer. This set was duplicated in a spiral fashion starting at the innermost ring near the ID and finishing at the outermost ring near the OD. 


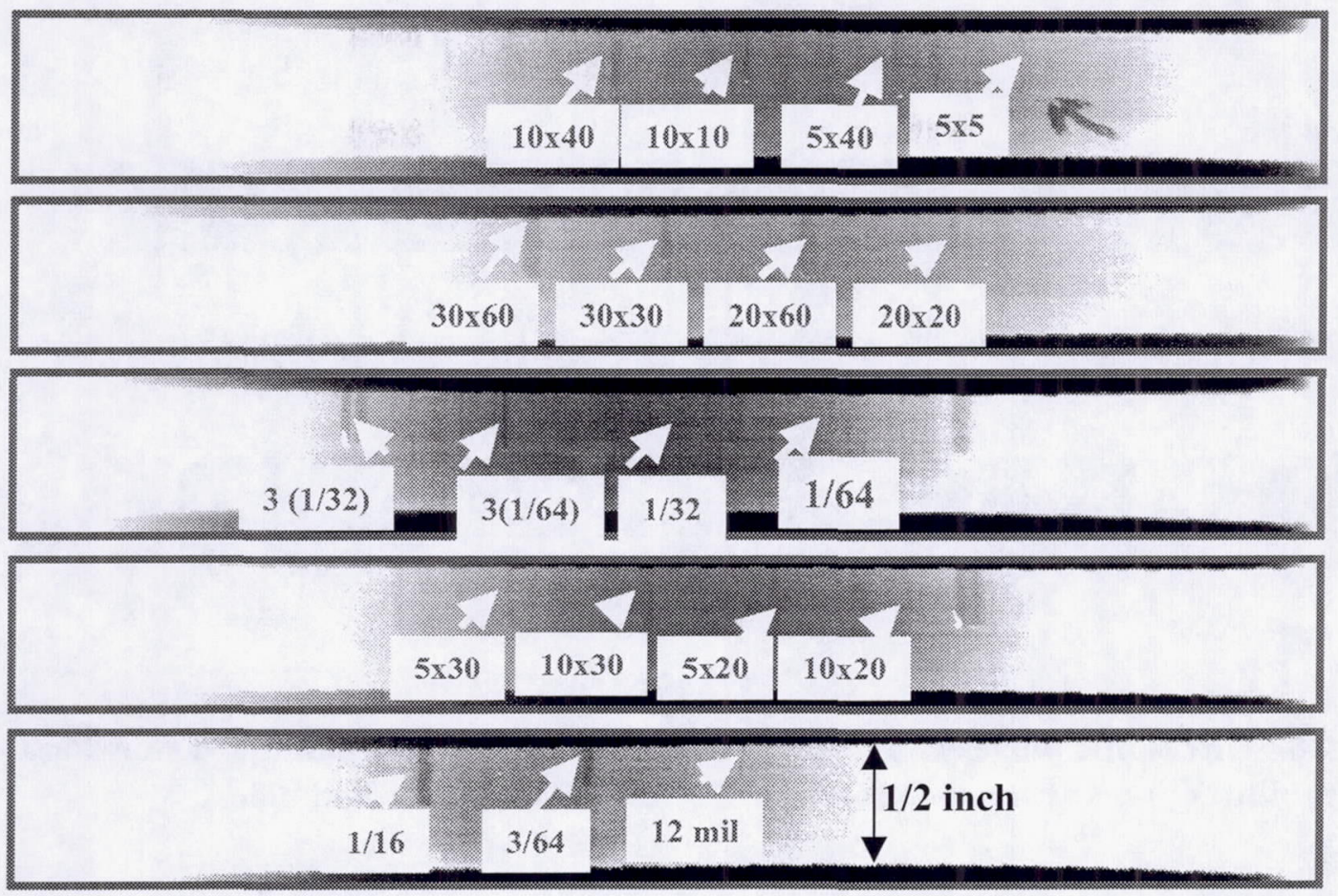

Fig. 6 - Microfocus radiography of one NDE ring standard showing the capabilities of detection down to $125 \times 125 \mu \mathrm{m}(5 \times 5$ mils $)$ notch. Measurements shown are in mils and images shown are prints of 5 radiographs taken in direct contact with the ID of the ring.

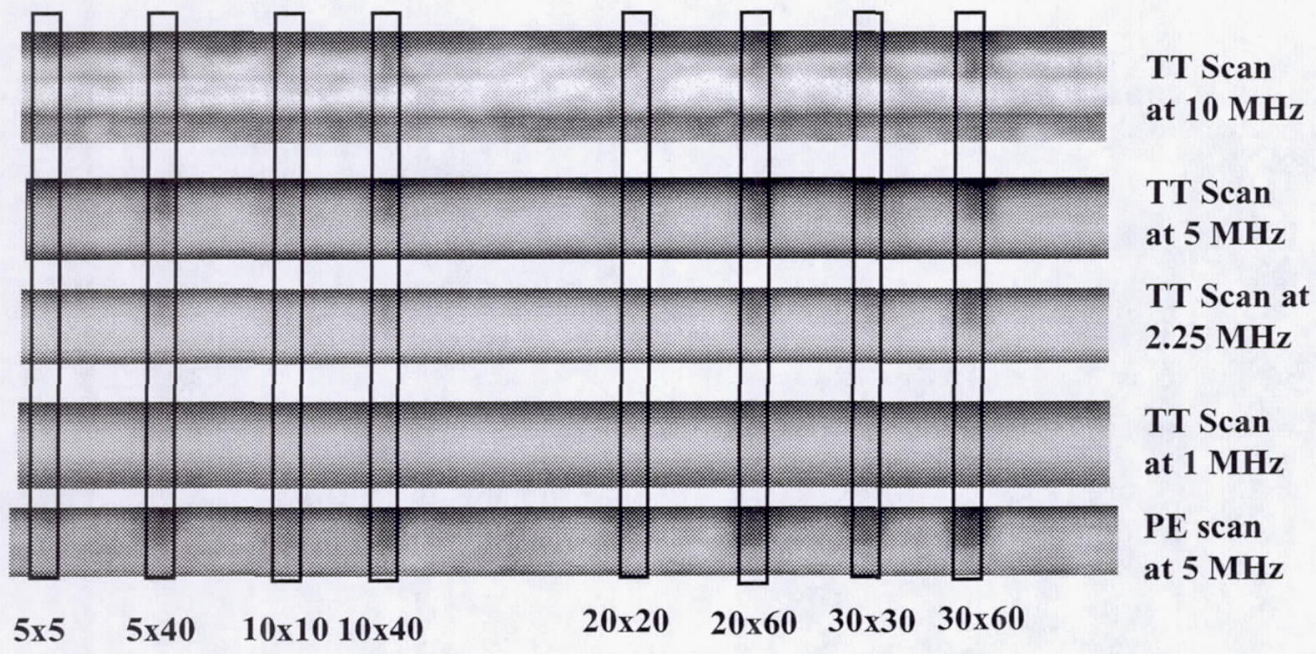

Defect or notch dimensions in mils

Fig. 7 - Ultrasonic scanning of one NDE ring standard showing the capabilities of detection with through transmission (TT) and pulse echo (PE) methods. The scans of the ring as displayed are open cylinders (rectangles) where the vertical direction represents the height of the ring and the horizontal direction represents the circumference from 0-359 degrees. 


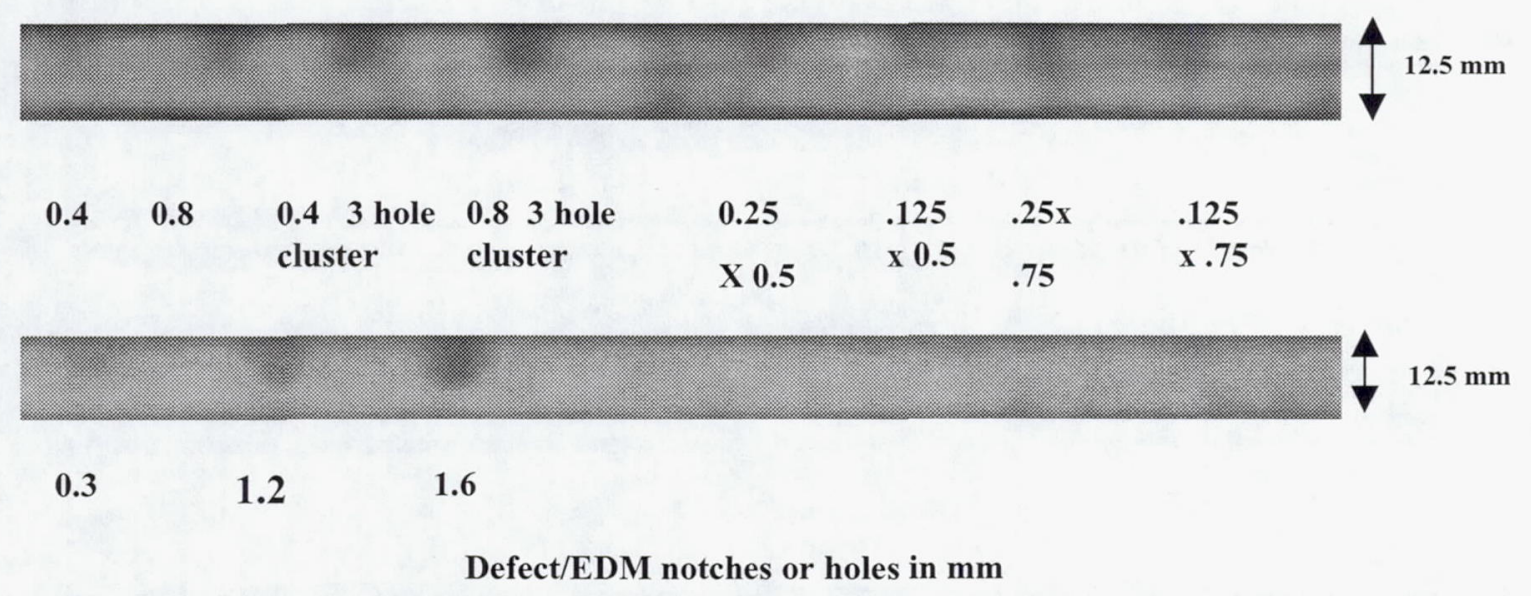

Fig. 8- Ultrasonic pulse echo $(5 \mathrm{MHz})$ scans of one NDE ring standard showing the capabilities of detecting $6.5 \mathrm{~mm}$ deep EDM notches and drilled holes

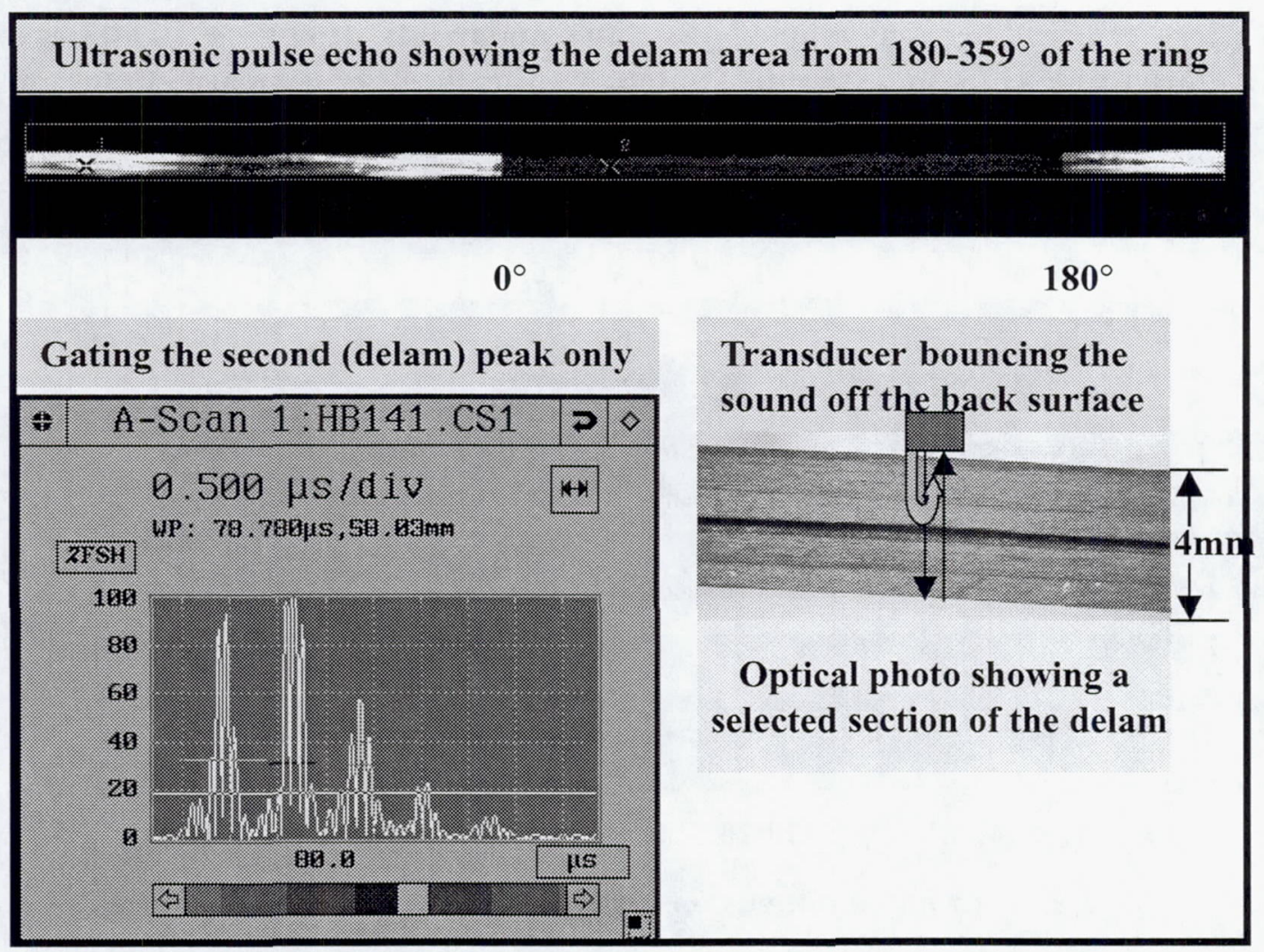

Fig. 9- Immersion pulse echo ultrasonic scan of a $180^{\circ}$ delam in a hydroburst ring 


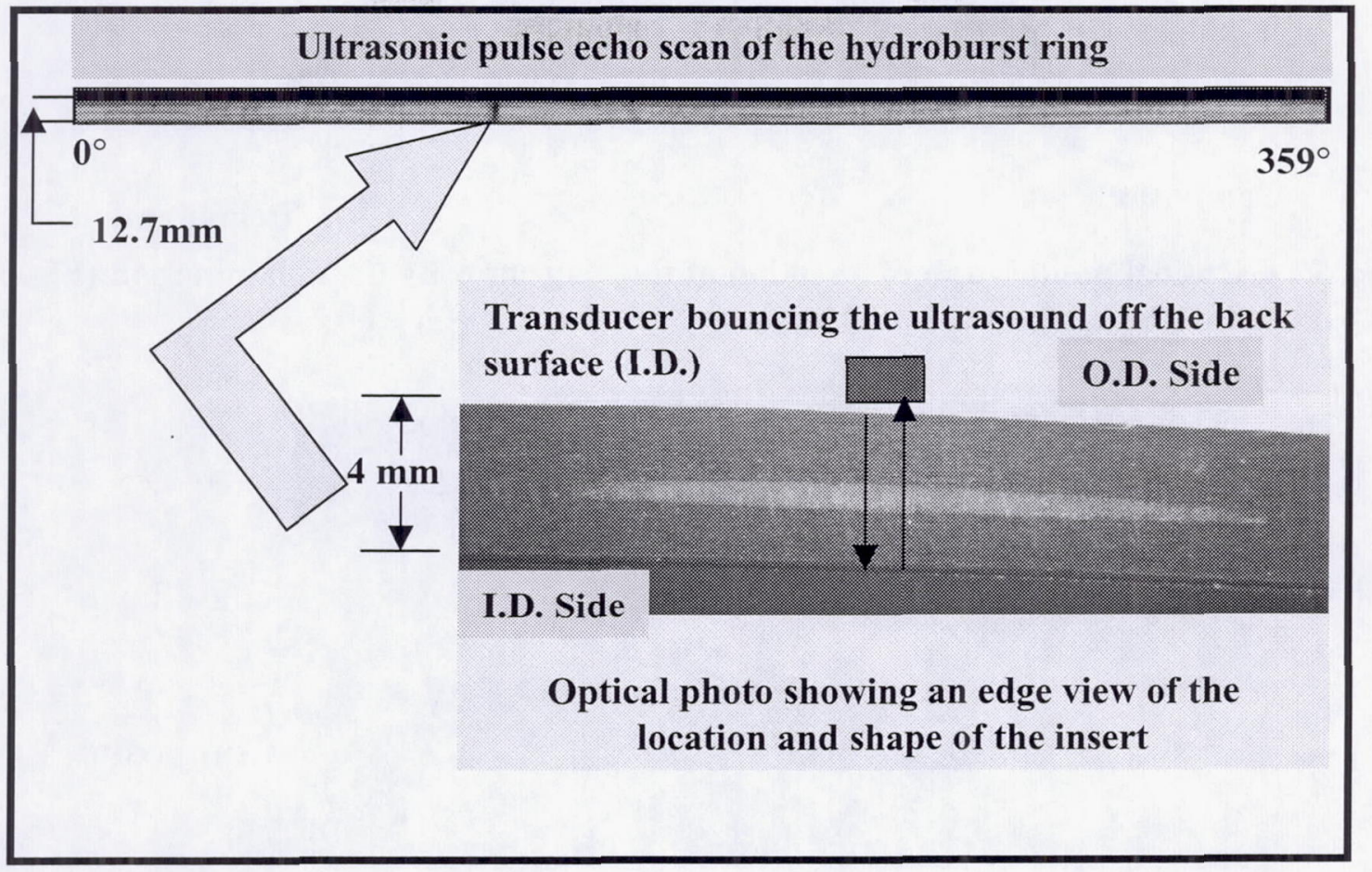

Fig. 10- Immersion ultrasonic pulse echo scan detects the insert of bagging material in a hydroburst ring

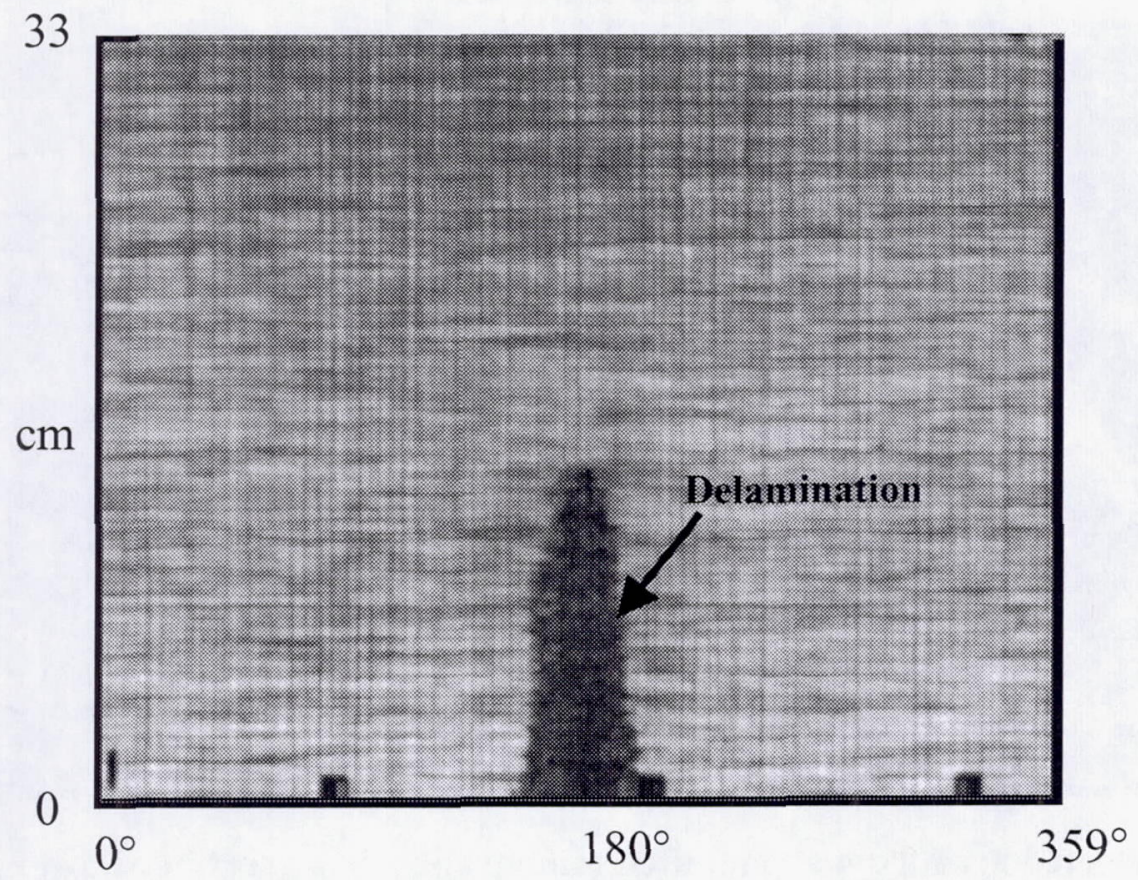

Fig. 11 - Ultrasonic scan showing a large delamination in one of the rings 


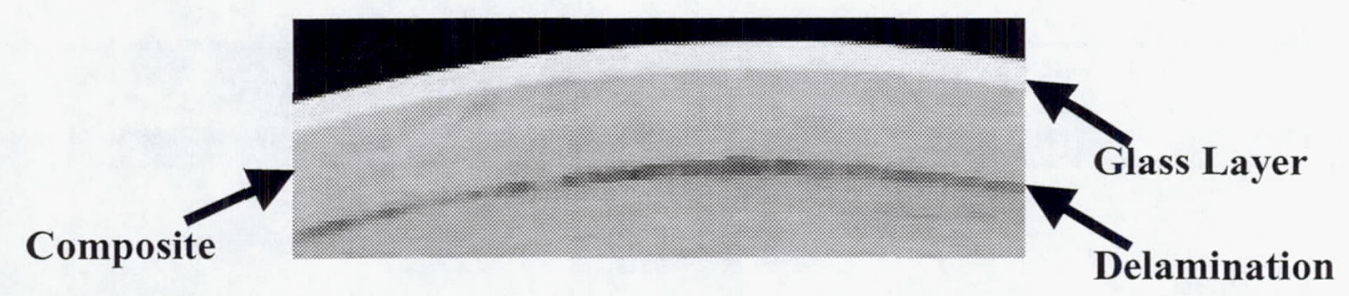

Fig. 12 - Optical photograph of a section of the ring showing the delamination (Fig. 11) as exposed to the surface

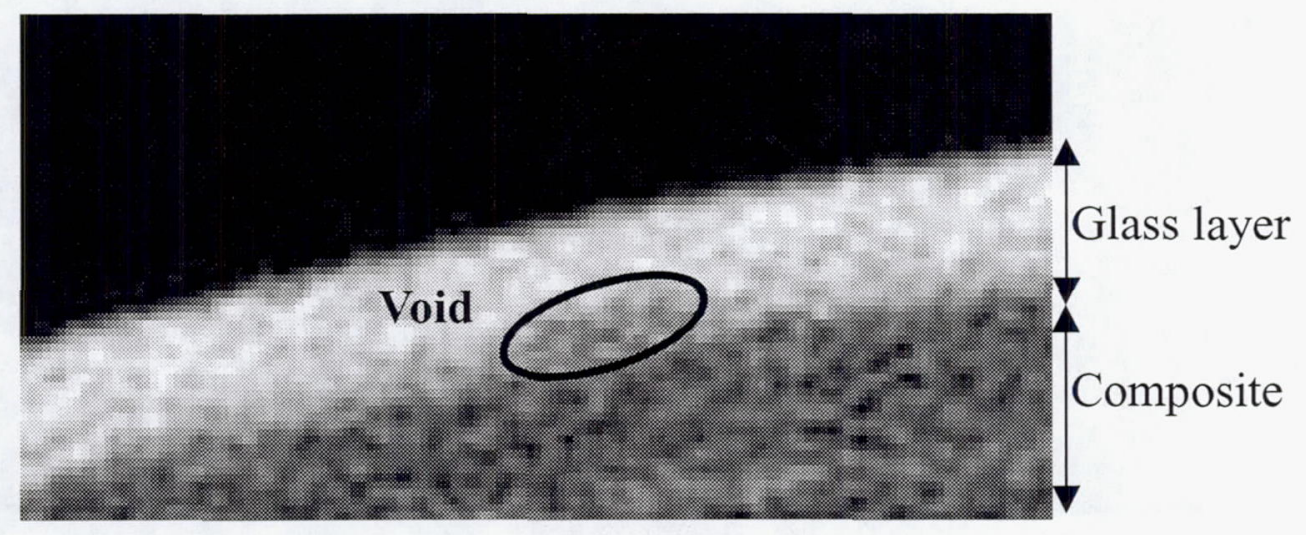

Fig. 13 - Selected section from the CT scan showing a $40 \times 80$ mils void in the glass layer

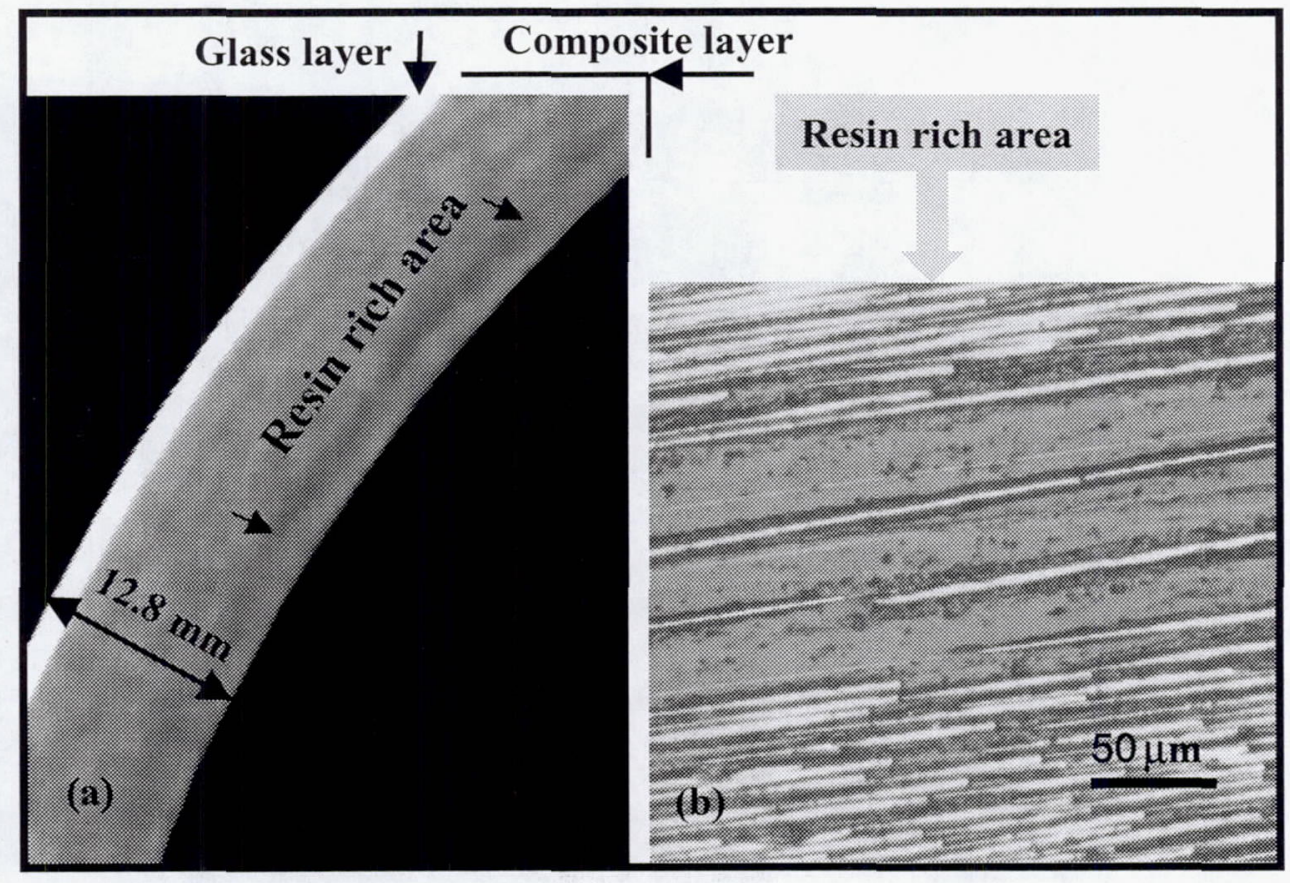

Fig. 14- Selected area from a computed tomography cross section showing a resin rich region within the composite layer (a), and an optical photograph of the resin rich region after destructive sectioning and polishing for validation (b) 
Public reporting burden for this collection of information is estimated to average 1 hour per response, including the time for reviewing instructions, searching existing data sources, gathering and maintaining the data needed, and completing and reviewing the collection of information. Send comments regarding this burden estimate or any other aspect of this collection of information, including suggestions for reducing this burden, to Washington Headquarters Services, Directorate for Information Operations and Reports, 1215 Jefferson Davis Highway, Suite 1204, Arlington, VA 22202-4302, and to the Office of Management and Budget, Paperwork Reduction Project (0704-0188), Washington, DC 20503.
1. AGENCY USE ONLY (Leave blank)
2. REPORT DATE 3. REPORT TYPE AND DATES COVERED
October 2000
Technical Memorandum

4. TITLE AND SUBTITLE 5. FUNDING NUMBERS

NDE Methodologies for Composite Flywheels Certification

6. AUTHOR(S)

WU-494-29-11-00

George Y. Baaklini, Kevin E. Konno, Richard E. Martin, and Richard Thompson

7. PERFORMING ORGANIZATION NAME(S) AND ADDRESS(ES)

National Aeronautics and Space Administration

John H. Glenn Research Center at Lewis Field

Cleveland, Ohio 44135-3191
8. PERFORMING ORGANIZATION REPORT NUMBER

E-12468
9. SPONSORING/MONITORING AGENCY NAME(S) AND ADDRESS(ES)

National Aeronautics and Space Administration

Washington, DC 20546-0001
10. SPONSORING/MONITORING AGENCY REPORT NUMBER

NASA TM-2000-210473

00PS-63

\section{SUPPLEMENTARY NOTES}

Prepared for the 2000 Power Systems Conference sponsored by the Society of Automotive Engineers, San Diego, California, October 31-November 2, 2000. George Y. Baaklini and Kevin E. Konno, NASA Glenn Research Center; Richard E. Martin, Cleveland State University, 1983 E. 24th St., Cleveland, Ohio 44115-2403; Richard Thompson, University of Texas at Austin, Austin, Texas 78712. Responsible person, George Y. Baaklini, organization code 5920, (216) 433-6016.

12a. DISTRIBUTION/AVAILABILITY STATEMENT 12b. DISTRIBUTION CODE

Unclassified - Unlimited

Subject Categories: 88 and 38

Distribution: Standard

Available electronically at http://gltrs.grc.nasa.gov/GLTRS

This publication is available from the NASA Center for AeroSpace Information, (301) 621-0390.

13. ABSTRACT (Maximum 200 words)

Manufacturing readiness of composite rotors and certification of flywheels depend in part on the maturity of nondestructive evaluation (NDE) technology for process optimization and quality assurance, respectively. Capabilities and limitations of $\mathrm{x}$-ray-computed tomography and radiography, as well as advanced ultrasonics were established on NDE ring and rotor standards with EDM notches and drilled holes. Also, intentionally seeded delamination, tow break, and insert of bagging material were introduced in hydroburst-rings to study the NDE detection capabilities of such anomalies and their effect on the damage tolerance and safe life margins of subscale rings and rotors. Examples of possible occurring flaws or anomalies in composite rings as detected by NDE and validated by destructive metallography are shown. The general NDE approach to ensure quality of composite rotors and to help in the certification of flywheels is briefly outlined.

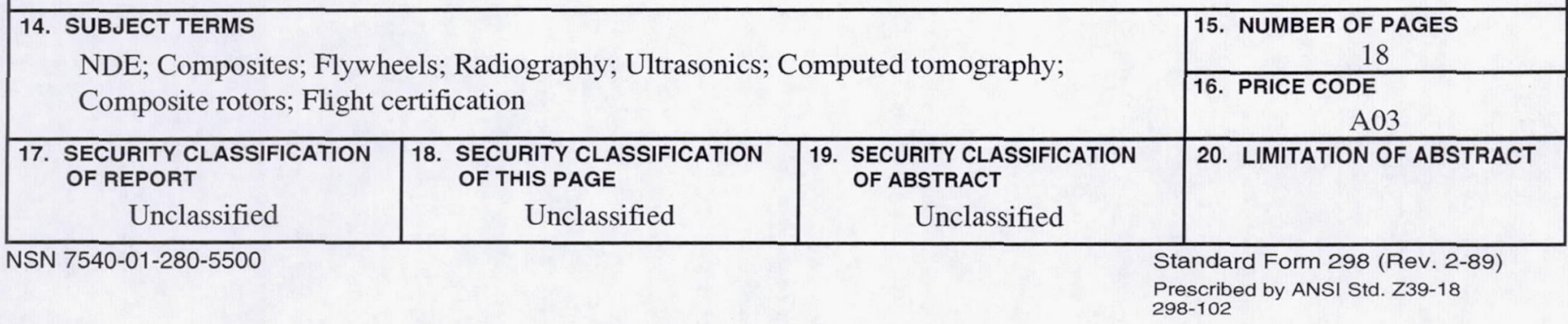

